\title{
Peran Guru pada Pengasuhan Anak dari Keluarga Tenaga Kerja Indonesia
}

\author{
Afifah Rahmaningrum ${ }^{1 凶}{ }^{\bowtie}$ Pujiyanti Fauziah $^{2}$ \\ Pendidikan Anak Usia Dini, Universitas Negeri Yogyakarta(1) \\ Pendidikan Luar Sekolah, Universitas Negeri Yogyakarta( ${ }^{(2)}$ \\ DOI: $10.31004 /$ obsesi.v5i2.796
}

\begin{abstract}
Abstrak
Penelitian ini bertujuan mendeskripsikan: (1) pola pengasuhan yang dilakukan dari pengasuh keluarga Tenaga Kerja Indonesia. (2) dampak dari pengasuhan keluarga Tenaga Kerja Indonesia terhadap aspek perkembangan anak usia dini. (3) peran serta guru terhadap pengasuhan yang dilakukan oleh pengasuh keluarga Tenaga Kerja Indonesia. (4) pengaruh positif peran guru di sekolah terhadap pengasuhan anak dari keluarga Tenaga Kerja Indonesia. (5) pengaruh positif peran guru terhadap aspek perkembangan anak usia dini. Penelitian ini menggunakan pendekatan deskriptif kualitatif. Teknik pengumpulan data wawancara, observasi, dan dokumentasi. Penelitian dilakukan di Desa Braja Luhur, Lampung Timur. Hasil penelitian: (1) pola pengasuhan permisif merupakan yang mayoritas diterapkan kepada anak. (2) dampak dari pengasuhan permisif terlihat di aspek sosial emosional, bahasa, dan kognitif. (3) peran serta guru pada pengasuhan adalah dengan memberikan pendekatan dan edukasi terhadap pengasuh dan juga anak. (4) terdapat perubahan secara perlahan ke arah positif terhadap pengasuhan. (5) terdapat perubahan secara perlahan terhadap perkembangan anak.
\end{abstract}

Kata Kunci: pengasuhan; anak usia dini; tenaga kerja indonesia; guru

\begin{abstract}
This study aims to describe: (1) the patterns of care provided by the Indonesian Migrant Workers' family. (2) the impact of caring for the Indonesian Workers' family on aspects of early childhood development. (3) the role of teachers in the care of the family caregivers of Indonesian Workers. (4) the positive influence of the role of teachers in schools on the care of children from families of Indonesian Workers. (5) the positive influence of the role of teachers on aspects of early childhood development. This research use desciptive qualitative approach. Data collection techniques are interviews, observation, and documentation. The research was conducted in Braja Luhur Village, East Lampung. The results of the study: (1) permissive parenting is the majority applied to children. (2) the impact of permissive parenting can be seen in the social, emotional, language and cognitive aspects. (3) the role of the teacher in care is to provide an approach and education for caregivers and children. (4) there is a gradual change in a positive direction towards parenting. (5) there is a gradual change in child development.
\end{abstract}

Keywords: parenting; early childhood; indonesian migrant workers; teachers

Copyright (c) 2020 Afifah Rahmaningrum, Pujiyanti Fauziah

$\triangle$ Corresponding author :

Email Address : afifahrahmaningrum.2019@student.uny.ac.id (Sleman, Daerah Istimewa Yogyakarta )

Received 2 October 2020, Accepted 29 October 2020, Published 7 November 2020 


\section{PENDAHULUAN}

Keluarga merupakan agen terdekat dengan anak yang sangat berpotensi menstimulasi anak sebagai lembaga pendidikan pertama serta menjadi titik utama dalam pertumbuhan dan perkembangan anak, secara realitas dapat diartikan juga sebagai suatu kelompok orang yang terdiri dari kepala keluarga dan anggotanya dalam ikatan nikah ataupun nasab yang hidup pada satu tempat tinggal, mempunyai aturan yang ditaati secara bersama dan mampu mempengaruhi antar anggotanya serta memiliki tujuan dan program yang jelas (Helmawati, 2014; Aziz, 2015). Pada keluarga tentunya terdapat pengasuhan yang diterapkan oleh orangtua, dan tentunya terdapat hubungan oleh masing-masing anggota keluarga. Pengasuhan ialah hubungan orangtua terhadap anak yang bertujuan untuk membimbing anak dari bayi hingga ke tahap dewasa dengan memberikan berbagai hal untuk mencukupi kebutuhan dan kepentingan hidup dari seorang anak (Hasan, 2009; Brooks, 2011).

Sehubungan dengan penjelasan tersebut, maka suatu pola interaksi pengasuhan dalam keluarga yang ideal seharusnya dapat mendukung proses perkembangan anak secara optimal yang meliputi seluruh aspek perkembangan anak usia dini yaitu kognitif, motorik, bahasa, dan sosial emosional. Anak juga dipersiapkan oleh keluarga untuk mampu berbahasa, berpendapat, berkreasi, berimajinasi, hingga mampu menghasilkan sesuatu adalah hasil dari pendidikan pertama yang diterima dalam keluarga.

Pada anak usia dini, pengasuhan bisa dilakukan oleh orangtua, guru, maupun orang yang lebih dewasa dan memiliki hubungan dengan anak. Terdapat beberapa faktor yang mempengaruhi pengasuhan orangtua kepada anak, diantaranya adalah tingkat sosio ekonomi orangtua yang tinggi dan rendah berpengaruh terhadap pengasuhan yang diberikan kepada anak (Berns, 2007). Keadaan sosial ekonomi ini berhubungan pada fungsi keluarga yaitu fungsi ekonomi, yang berhubungan dengan penghasilan yang diperoleh serta pemenuhan kebutuhan dalam keluarga (Hasbi Indra, 2017). Orangtua sebagai pemegang kewajiban dalam memenuhi kebutuhan keluarga tentunya harus memiliki pekerjaan. Salah satu pekerjaan yang ada yaitu Tenaga Kerja Indonesia (TKI) yang bekerja di luar daerah domisili tinggal.

Tenaga Kerja Indonesia adalah setiap warga Indonesia yang memenuhi syarat untuk bekerja di luar negeri dalam hubungan kerja dalam jangka waktu tertentu dengan menerima upah (DPR, 2014). Sudah dapat dipastikan bahwa apabila orangtua memiliki pekerjaan Tenaga Kerja Indonesia (TKI) maka akan tinggal berjauhan dengan anak. Hal ini mengakibatkan salah satu orangtua ataupun kakek-nenek harus memiliki peran ganda dalam proses pengasuhan anak.

Mayoritas pada anak yang memiliki orangtua TKI akan diasuh oleh orang tua pengganti (kakek-nenek) yang menerapkan pola pengasuhan tertentu. Hal ini menyebabkan permasalahan pada pengasuhan anak usia dini yang tidak dijalankan langsung oleh orangtuanya. Pengasuhan yang diterapkan orangtua dalam keluarga akan mempengaruhi kehidupan anak di masa depan. Berbagai jenis pengasuhan memiliki sisi positif dan negatif terhadap perilaku anak. Terdapat berbagai jenis pengasuhan diantaranya yaitu otoritatif, otoritarian, permisif, dan mengabaikan (Baumrind, 1991).

Orang tua pengganti (kakek-nenek) seringkali menuruti kemauan anak dan tidak mampu mengindahkan atau membatasi apakah itu baik atau tidak bagi anak sendiri. Orang tua pengganti (kakek-nenek) juga tidak tegas dan mentoleransi perilaku anak yang tidak baik, mendorong anak berperilaku semaunya sendiri (Sutiana et al., 2018). Hal serupa juga sesuai dengan hasil penelitian bahwa pengasuhan yang dilakukan oleh nenek pada keluarga TKI di Kecamatan Gekbrong, Cianjur-Jawa Barat tidak cukup memberikan kontribusi terhadap perkembangan emosi remaja pada anak keluarga TKI (Nurannisa et al., 2017).

Menurut Graham \& Jordan (Nopitasari \& Imelda, 2018) bahwa anak-anak yang ditinggal bermigrasi oleh salah seorang ataupun kedua orangtua mereka akan berpeluang mengalami gangguan psychological wellbeing yang lebih besar seperti gangguan emosi, daripada anak yang tinggal dengan kedua orangtua mereka. Psychological wellbeing dapat 
diartikan sebagai suatu kesejahteraan psikologis yang ada pada individu (Nayana, 2013). Studi logitudional yang dilakukan oleh Brook-Gunn, Han, \& Waldfogrl (Santrock, n.d.) bahwa anak usia tiga tahun dari ibu yang bekerja memiliki kemampuan kognitif yang lebih rendah daripada anak usia tiga tahun yang ibunya tinggal di rumah pada sembilan bulan pertama kehidupan anak. Hasil penelitian Hidayati \& Zuhdi (2019) menemukan bahwa orangtua yang bekerja sebagai Tenaga Kerja Indonesia (TKI) mampu memenuhi kebutuhan jasmani anak, namun kebutuhan rohani anak yaitu dalam aspek kemampuan sosial emosional seperti kedisplinan masih belum bisa diberikan secara optimal.

Apabila orangtua bekerja di luar negeri, maka pengasuhan akan beralih kepada kakek ataupun nenek dari anak. Berdasarkan hasil penelitian (Suharto \& Nurwati, 2018) didapatkan bahwa pengasuhan yang diberikan oleh nenek, maka akan terjadi pengasuhan yang memanjakan cucu, memenuhi semua keinginan anak yang diasuh, serta nenek jarang memarahi anak. Dampak dari pengasuhan ini terhadap anak adalah menjadikan anak seorang pribadi yang manja serta memiliki tingkat kepatuhan yang tidak begitu baik.

Guru sebagai yang berperan penting dalam perkembangan anak usia dini, tentunya memiliki peran untuk menstimulasi perkembangan anak dan memberikan arahan yang optimal oleh pengasuhan permissive dari kakek-nenek. Ki Hajar Dewantara menyatakan bahwa pendidik yang menjadi teladan bagi anak didiknya dapat mengarahkan dan menuntun dengan benar tanpa adanya paksaan potensi yang dimiliki oleh peserta didik agar mereka menjadi manusia yang merdeka batinnya, pikirannya, serta tenaganya dan dengan pendidikan, mereka dapat menjadi manusia yang berguna bagi nusa, bangsa dan agama, sehingga bisa mengangkat derajat negaranya (Setiawan, 2017).

Oleh sebab itu berdasarkan penelitian yang telah dilakukan maka dapat dijadikan dasar bahwa perlu adanya penelitian terkait peran guru pada pengasuhan yang diterapkan oleh keluarga Tenaga Kerja Indonesia. Pada penelitian ini bertujuan untuk mengetahui pola asuh yang diterapkan pada anak usia dini yang berasal dari keluarga Tenaga Kerja Indonesia, dampak dari pengasuhan, bagaimana peran guru di sekolah terhadap pengasuh pada anak usia dini yang berasal dari keluarga Tenaga Kerja Indonesia, dan pengaruh positif peran guru terhadap pengasuhan dan aspek perkembangan anak. Anak usia dini yang dituju adalah anak usia taman kanak-kanak yang bersekolah di Desa Braja Luhur, Lampung Timur. Hasil dari adanya penelitian ini yaitu diharapkannya pemahaman dari keluarga serta guru di daerah yang memiliki warga sebagai Tenaga Kerja Indonesia terkait pengasuhan dan mendukung seluruh aspek perkembangan anak usia dini.

\section{METODOLOGI}

Penelitian ini menggunakan metode deskriptif kualitatif. Teknik analisis data dalam penelitian deskriptif kualitatif (Sugiyono, 2015) yaitu dengan mencari, menyusun data dengan sistematis yang diperoleh diantaranya dari hasil wawancara, observasi, dan dokumentasi. Data yang diperoleh yakni sudut pandang dari subjek penelitian melalui wawancara tidak terstruktur yaitu wawancara yang menggunakan garis besar permasalahan, observasi non partisipan yaitu pengamatan yang tidak terlibat secara langsung, dan kemudian untuk memperkuat penelitian ini digunakan juga dokumentasi (Sugiyono, 2017). Lokasi penelitian berada di Desa Braja Luhur, Lampung Timur, pemilihan lokasi Provinsi Lampung dikarenakan merupakan provinsi di Indonesia terbesar kelima yang merupakan daerah asal pekerja migran (Badan Pelindungan Pekerja Migran Indonesia, 2020). Penelitian ini dilakukan pada bulan April-Mei 2020.

Menurut (Sugiyono, 2017) dalam penelitian yang bercirikan kualitatif tidak menggunakan istilah populasi, melainkan situasi sosial yang terdiri atas tiga elemen yaitu tempat, pelaku, dan aktivitas yang berinteraksi secara sinergis. Kemudian yang menjadi informan dalam penelitian ini adalah guru di taman kanak-kanak yang berlokasi di Desa Braja Luhur, dua guru yaitu guru pada kelompok A dan kelompok B. Teknik sampling yang 
digunakan adalah purposive sampling yaitu pengambilan sampel sumber data dengan didasarkan beberapa pertimbangan tertentu.

Tahap analisis data dalam penelitian deskriptif kualitatif secara umum di mulai sejak pengumpulan data dilanjutkan beberapa tahap yaitu (Sugiyono, 2017; Sutiana et al., 2018) reduksi data, yang diartikan sebagai proses pemilihan, pemusatan perhatian pada penyederhanaan, pengabstrakan, dan transformasi data kasar yang muncul, selanjutnya yakni proses penyajian data dilakukan dengan menggunakan bentuk teks naratif, dan yang terakhir, dilakukan penarikan kesimpulan serta verifikasi. Analisis data dalam penelitian ini dilakukan setelah data-data diperoleh melalui teknik wawancara dan observasi. Kemudian data-data yang sudah didapat dianalisis secara saling berhubungan untuk mendapatkan dugaan sementara (hipotesis), yang dipakai sebagai dasar untuk mengumpulkan data, lalu dilakukan konfirmasi kepada informan secara terus menerus sebagai triangulasi. Data primer dan data sekunder yaitu berupa hasil wawancara, observasi, dan foto. Melalui langkah-langkah yang sudah diterapkan akan diberikan gambaran hasil dari jawaban atas pertanyaan yang diajukan ke informan pada wawancara, kemudian disusun menjadi laporan hasil penelitian dalam bentuk deskriptif.

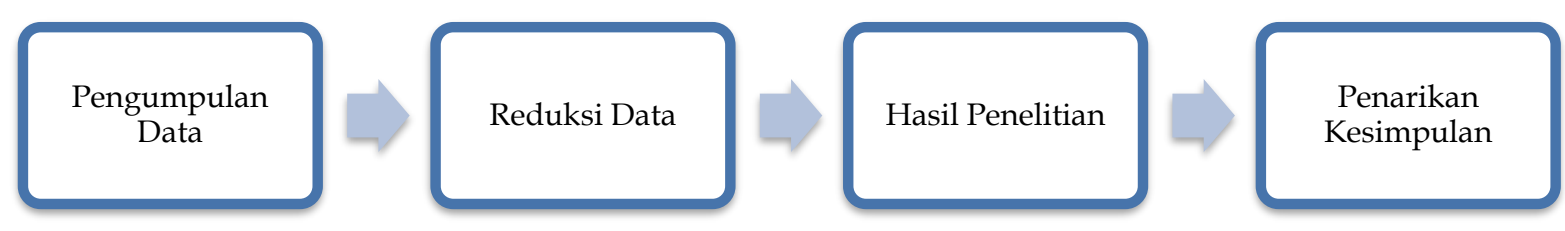

Gambar 1. Alur Penelitian

\section{HASIL DAN PEMBAHASAN \\ Pola Pengasuhan}

Terdapat beberapa anak usia dini di Desa Braja Luhur yang memiliki orangtua yang bekerja sebagai Tenaga Kerja Indonesia (TKI) di luar negeri. Orangtua yang bekerja sebagai Tenaga Kerja Indonesia (TKI) mayoritas adalah Ibu, kemudian Ayah akan menetap di rumah ataupun turut merantau namun tetap di pulau Sumatera seperti kota Jambi dan Pekanbaru. Komunikasi yang terjalin antara anak dan Ibu yang bekerja biasanya melalui media handphone. Kepulangan Ibu ke Indonesia tidak tentu bisa dilakukan setiap tahun, bahkan banyak yang lebih dari 1 tahun. Ayah yang ditinggal istrinya bekerja sering dibantu oleh keluarga besar seperti kakek nenek, paman dan bibi dari anak-anak. Reposisi ini dapat berdampak pada sikap dan perilaku anak-anak, gaya hidup, gaya pengasuhan, dan perkembangan kepribadian anak-anak (Slamet et al., 2018).

Anak yang ditinggalkan orangtuanya bekerja ini akan tinggal dan diasuh oleh kakek nenek. Dari data anak yang bersekolah di salah satu taman kanak-kanak di Desa Braja Luhur tahun 2019/2020 pada kelompok A terdapat 3 anak yang berasal dari keluarga Tenaga Kerja Indonesia (TKI) dari total 19 anak. Kemudian pada kelompok B terdapat 4 orang anak yang berasal dari keluarga Tenaga Kerja Indonesia (TKI) dari total 19 anak.

Berdasarkan hasil wawancara, ditemukan bahwa pola pengasuhan yang mayoritas diterapkan oleh kakek nenek pada anak-anak tersebut adalah pola asuh permisif. Kakek nenek menuruti seluruh kemauan anak seperti memberikan sesuatu sesuai dengan permintaan anak. Selain itu, pada aspek sosial emosional, kakek nenek juga mayoritas kurang membiasakan kemandirian kepada anak, yaitu anak masih sering disuapi, dimandikan, dan dipakaikan baju. Pekerjaan yang diberikan oleh guru di sekolah juga mayoritas apabila anak tidak bisa akan dikerjakan oleh kakek nenek. Anak juga masih ditunggu oleh kakek nenek ketika di sekolah, sehingga terbiasa melakukan apapun dengan bantuan. Kakek nenek cenderung tidak memberikan hukuman kepada anak, sehingga anak tidak terbiasa mendapatkan penjelasan dan konsekuensi dari apa yang mereka lakukan. Meskipun begitu tetap ada pembiasaan positif yang dilakukan oleh kakek nenek, diantaranya dengan 
mengenalkan agama islam kepada anak dengan mengikutkan pada lembaga baca Qur'an yang ada di desa.

Tabel 1. Jenis Pengasuhan Menurut Baumrind (1991)

\begin{tabular}{|c|c|}
\hline $\begin{array}{c}\text { Jenis } \\
\text { Pengasuhan }\end{array}$ & Penjelasan \\
\hline Otoriter & $\begin{array}{l}\text { Adalah gaya pengasuhan yang membatasi dan relatif memberikan hukuman pada } \\
\text { anak. Orangtua mendesak anak untuk mengikuti arahan mereka serta } \\
\text { menghormati pekerjaan dan upaya mereka. Orangtua yang otoriter menerapkan } \\
\text { batas dan kendali yang tegas pada anak dan meminimalisir perdebatan verbal. } \\
\text { Orangtua otoriter sering memukul anak, memaksakan aturan secara kaku tanpa } \\
\text { menjelaskannya, dan menunjukkan amarah pada anak. }\end{array}$ \\
\hline Otoritatif & $\begin{array}{l}\text { Gaya pengasuhan ini mendorong anak untuk mandiri namun masih menerapkan } \\
\text { batas dan kendali pada tindakan mereka. Orangtua bersikap hangat dan } \\
\text { penyayang terhadap anak, serta mengutamakan dialog dan diskusi. Orangtua } \\
\text { yang otoritatif menunjukkan kesenangan dan dukungan sebagai respons terhadap } \\
\text { perilaku konstruktif anak. Orangtua juga mengharapkan perilaku anak yang } \\
\text { dewasa, mandiri, dan sesuai dengan usianya. }\end{array}$ \\
\hline Mengabaikan & $\begin{array}{l}\text { Gaya pengasuhan ini dicirikan dengan orangtua yang sangat tidak terlibat dalam } \\
\text { kehidupan anak. Anak yang memiliki orangtua yang mengabaikan merasa bahwa } \\
\text { aspek lain kehidupan orangtua lebih penting daripada diri mereka. }\end{array}$ \\
\hline Permisif & $\begin{array}{l}\text { Pada gaya pengasuhan ini, orangtua sangat terlibat dengan anak, namun tidak } \\
\text { terlalu menuntut dan mengontrol mereka. Orangtua membiarkan anak melakukan } \\
\text { apa yang diinginkan. Pola asuh permisif adalah pengasuhan yang menuruti } \\
\text { seluruh kemauan serta tidak menerapkan aturan kepada anak. Anak cenderung } \\
\text { akan berkelakuan semena-mena serta bebas melakukan apapun yang diinginkan. } \\
\text { Pola asuh permisif ini memiliki sifat children centered yaitu anak menjadi pusat } \\
\text { dalam menetapkan segala aturan dalam keluarga, orang lain tidak memiliki } \\
\text { kewenangan dalam memutuskan hal-hal yang akan diberlakukan kepada anak. }\end{array}$ \\
\hline
\end{tabular}

\section{Dampak Pengasuhan}

Pengasuhan yang diterapkan oleh kakek nenek terhadap anak yang memiliki orangtua sebagai Tenaga Kerja Indonesia memiliki dampak tersendiri terhadap aspek perkembangan anak. Menurut para guru di sekolah, dijelaskan bahwa anak cenderung kurang optimal dalam perkembangan sosial emosionalnya. Kemampuan kemandirian, disiplin, dan percaya diri merupakan hal yang paling mencolok memiliki perbedaan dengan anak lain. Anak cenderung belum bisa untuk mengerjakan dan menyelesaikan kegiatan yang diberikan oleh guru. Apapun yang anak kerjakan terkadang bergantung pada kakek-nenek, sehingga justru anak memberikan tugas kepada kakek-nenek serta cenderung kurang mampu menyelesaikan tugas dengan kemampuannya sendiri.

Permasalahan lain yang ditemui oleh guru di sekolah, adalah pada perkembangan kognitif dan bahasa anak. Capaian kemampuan bahasa yang kurang pada anak yang memiliki orang tua Tenaga Kerja Indonesia (TKI) dalam kegiatan pengenalan membaca huruf. Sedangkan pada kognitif yaitu pada kurangnya pengenalan anak terhadap angka dan lambang bilangan. Hal ini berimbas pada kurangnya pemahaman anak dalam kegiatan penjumlahan dan pengurangan. Hal ini juga tetap ditemui meskipun kegiatan tersebut telah menggunakan alat bantu berupa benda dalam wujud nyata. Permasalahan tersebut dapat sebagaimana ditampilkan pada tabel 2.

Berdasarkan pendapat Brooks (Haryanti \& Sumarno, 2014) dapat ditegaskan bahwa kendala yang muncul terhadap pengasuhan anak disebabkan oleh perubahan keluarga dalam tipe diverse family form, yaitu orangtua yang harus bekerja atau berkarier untuk memenuhi kebutuhan keluarga. Hal ini dilakukan oleh kedua orangtua maupun orangtua tunggal (single parent). Kesibukan orangtua yang menyebabkan pengasuhan anak menjadi kurang optimal, 
maka orangtua melakukan pendelegasian tugas pengasuhan kepada keluarga besar maupun kepada orang lain. Menurut (Brooks, 1986) terdapat beberapa tugas bagi orangtua dalam pengasuhan, yaitu: a) Memberikan kasih sayang dan selalu memiliki hubungan dengan anak, b) Memberikan akses kebutuhan medis atau kesehatan, c) Menerapkan disiplin yang bertanggungjawab, d) menghindarkan dari hal-hal yang berbahaya seperti kecelakaan dan kritikan peda serta hukuman fisik, e) Memberikan pendidikan intelektual dan moral, f) Mempersiapkan anak untuk bertanggungjawab sebagai orang dewasa, g) Mempertanggungjawabkan tindakan anak kepada masyarakat luas.

Tabel 2. Permasalahan Pada Aspek Perkembangan

\begin{tabular}{ll}
\hline \multicolumn{1}{c}{ Aspek } & \multicolumn{1}{c}{ Permasalahan } \\
\hline Sosial Emosional & $\begin{array}{l}\text { Secara keseluruhan kemampuan anak sudah sesuai dengan beberapa tahapan } \\
\text { perkembangan sosial emosional, hanya anak kurang mandiri, disiplin, dan } \\
\text { percaya diri dalam melaksanakan kegiatan karena masih sering mendapat } \\
\text { bantuan dari kakek ataupun nenek. }\end{array}$ \\
\hline Kognitif & $\begin{array}{l}\text { Secara keseluruhan kemampuan anak sudah sesuai dengan beberapa tahapan } \\
\text { perkembangan kognitif, namun anak masih kurang dalam pengenalan angka } \\
\text { dan lambang bilangan. }\end{array}$ \\
\hline Bahasa & $\begin{array}{l}\text { Secara keseluruhan kemampuan anak sudah sesuai dengan beberapa tahapan } \\
\text { perkembangan bahasa, namun anak masih kurang dalam pengenalan huruf. }\end{array}$ \\
\hline
\end{tabular}

Pada pengasuhan permisif, anak menerima sedikit bimbingan yang membuat mereka tidak yakin dan cemas tentang apakah mereka sudah melakukan hal yang benar atau belum (Papalia et al., 2015). Sehingga anak kurang memiliki kesempatan untuk belajar mengendalikan perilakunya sendiri dan selalu berharap mendapatkan keinginannya. Beberapa orangtua sengaja membesarkan anak mereka dengan pola pengasuhan permisif agar menghasilkan anak yang kreatif dan percaya diri. Namun pada kenyataannya apabila dilakukan tanpa batasan justru bisa menghasilkan anak yang jarang belajar menghormati orang lain, mengalami kesulitan untuk mengendalikan perilakunya, egosentris, tidak menuruti aturan, dan kesulitan dalam hubungan dengan teman sebaya (Santrock, n.d.).

Anak dengan pola asuh permisif cenderung akan menjadi lebih baik dan menunjukkan vitalitasnya dibandingkan anak dari keluarga dengan pola pengasuhan otoriter. Orangtua yang serba membolehkan akan mendorong anak menjadi agresif dan cenderung tidak percaya diri (Hasan, 2009). Anak cenderung bertindak semena-mena, bebas melakukan apa saja yang diinginkannya tanpa memandang bahwa itu sesuai dengan nilai-nilai atau norma yang berlaku atau tidak. Sisi negatif dari pola asuh ini adalah anak kurang disiplin dengan aturan sosial yang berlaku. Sisi positifnya jika anak menggunakannya dengan tanggungjawab maka anak akan menjadi seorang yang mandiri, kretif, nisiatif, dan mampu mewujudkan aktualisasi dirinya di masyarakat (Hasbi Indra, 2017).

Ibu bekerja sebagai Tenaga Kerja Indonesia (TKI) untuk mendapatkan kecukupan dalam sisi ekonomi. Dengan adanya peningkatan kekayaan keluarga akan mendorong konsumsi mereka baik secara langsung maupun tidak langsung (Cao et al., 2017). Hal ini juga berhubungan dengan kakek nenek yang cenderung menuruti kemauan anak karena orangtua mengirimkan dan memiliki uang yang banyak untuk memanjakan anak. Sehingga segala kebutuhan dan keinginan anak hampir selalu dipenuhi oleh kakek-nenek.

Terdapat beberapa efek bagi anak yang ditinggal oleh orangtuanya bekerja migran. Selain dari pola asuh yang tentunya akan berbeda dengan yang dilakukan oleh ibunya sendiri, anak-anak migran juga mengalami berbagai risiko dan kondisi kesehatan (Nichols et al., 2014). Selain itu pada keluarga tenaga kerja wanita yang menyebabkan anak sudah ditinggal ibunya sejak kecil yaitu di masa balita maka pola komunikasi dan pola asuh tidak berjalan dengan baik di keluarga tersebut (Sutiana et al., 2018). 
Anak-anak dari keluarga Tenaga Kerja Indonesia (TKI) biasanya dicukupi kebutuhan fisiknya secara berlebih oleh kakek dan neneknya dari hasil sang ibu sebagai tenaga kerja wanita namun kebutuhan rohani dan kasih sayang dari ibu tidak akan sepenuh pada anak dari orangtua dengan pekerjaan yang lain (Yuniastuti, 2014). Pada aspek perkembangan anak usia dini terdapat beberapa permasalahan di aspek sosial emosional, kognitif, dan bahasa. Anak dari keluarga Tenaga Kerja Indonesia (TKI) karena mendapatkan pengasuhan permisif, cenderung kurang mandiri, percaya diri, dan disiplin. Anak dengan orang tua yang bekerja sebagai TKI memiliki perilaku disiplin belajar yang rendah (Hidayati et al., 2019).

Permasalahan lain yang ditemui oleh guru adalah pada aspek perkembangan kognitif. Hal ini juga dikarenakan orangtua ataupun kakek nenek kurang optimal dalam menstimulasi keseluruhan aspek perkembangan anak. Peran orang tua yang baik dalam kegiatan bermain akan menimbulkan dampak yang baik pula dalam perkembangan kognitif anak prasekolah sedangkan peran orang tua yang kurang peduli akan menimbulkan dampak yang tidak baik pula bagi perkembangan kognitif anak prasekolah, beberapa dampaknya yaitu, anak akan menjadi anak yang tidak ceria, kurang percaya diri, kurang supel, bahkan mudah takut pada teman-temannya, dan kurang kreatif (Herentina.T, 2012). Pada penelitian tersebut juga ditemukan bahwa perkembangan kognitif yang baik disebabkan karena taraf intelegensi atau kognitif sangatlah ditentukan oleh pengalaman dan pengetahuan yang diperolehnya dari lingkungan hidupnya. Lingkungan yang dimaksud adalah lingkungan tempat tinggal dan juga lingkungan sekolah yang turut membentuk perkembangan kognitif anak tersebut. Selain faktor lingkungan, faktor pembentukan juga turut berperan dalam perkembangan kognitif anak. Pembentukan yang turut berperan dalam perkembangan kognitif anak adalah pembentukan sengaja, yaitu melalui sekolah diantaranya yaitu taman kanak-kanak.

Aspek lain yang juga kurang terstimulasi dengan baik oleh anak yang berasal dari keluarga Tenaga Kerja Indonesia (TKI) adalah aspek perkembangan bahasa. Hal ini dikarenakan kurangnya komunikasi ibu dengan anak, sedangkan anak diasuh oleh kakek nenek. Menurut penelitian Safitri (2017) untuk mendapatkan perkembangan bahasa yang sesuai dengan usia balita diperlukan pengetahuan ibu yang tinggi, dimana ibu sebagai pihak yang secara umum memiliki waktu interaksi lebih banyak dengan anak, perlu memiliki pengetahuan tentang tumbuh kembang serta bagaimana menstimulasinya. Pengetahuan ibu yang baik juga harus didukung dengan pola asuh yang positif agar perkembangan bahasa balita dapat sesuai dengan usianya. Menurut penelitian terdahulu juga ditemukan bahwa jenis pola asuh yang diterapkan merupakan salah satu faktor yang mempengaruhi perkembangan bahasa balita, karena dari pola asuh ini dapat terbentuk kepribadian balita dalam tumbuh kembang dan perkembangan bahasanya (Safitri, 2017). Dengan pola asuh yang positif seperti sering mengajak bermain dengan teman sebaya, bersosialisasi dengan lingkungan luar dan memberikan banyak waktu orang tua terutama ibu dirumah akan dapat membantu stimulasi perkembangan bahasa dari anak usia dini. Hasil penelitian ini sejalan dengan penelitian yang dilakukan oleh Graham \& Jordan (Nopitasari \& Imelda, 2018) bahwa anak-anak yang ditinggal bermigrasi oleh salah seorang ataupun kedua orangtua mereka akan berpeluang mengalami gangguan psychological wellbeing yang lebih besar seperti gangguan emosi, daripada anak yang tinggal dengan kedua orangtua mereka.

Anak yang memiliki Ibu bekerja sebagai Tenaga Kerja Indonesia (TKI) menurut pelaporan guru memiliki capaian kemampuan sosial emosional yang kurang optimal. Hal ini didukung oleh hasil penelitian yang menemukan bahwa perkembangan sosial emosi anak dipengaruhi secara signifikan oleh kelekatan ibu-anak, pertumbuhan anak, lama pendidikan ibu, dan status pekerjaan ibu (Wijirahayu et al., 2016). Kelekatan ibu dan anak berpengaruh positif signifikan terhadap perkembangan sosial emosi anak. Megawangi (dalam Wijirahayu et al., 2016) juga menyatakan bahwa anak dengan kelekatan tidak aman (insecure attachment) akan sulit mengatur emosinya sehingga apabila ada larangan atau keinginan yang tidak terpenuhi, anak akan merengek, menangis meraung-raung, berguling-guling, atau bahkan mengamuk (temper tantrum). Sebaliknya, anak dengan secure attachment akan memiliki 
kemampuan untuk mengatur emosi. Hal ini akan membawa pengaruh positif dalam proses perkembangan sosial emosi anak. Oleh karena itu, kelekatan ibu tidak hanya memberikan kehangatan secara fisik namun juga kognitif dan afektif bagi anak beserta ibu.

\section{Peran Guru}

Ketika guru sudah memiliki kelekatan dengan anak, maka guru dapat mengetahui kemampuan serta hal yang belum dikuasai oleh anak. Pemberian penguatan kepada anak dari keluarga Tenaga Kerja Indonesia (TKI) diberikan lebih banyak daripada dengan teman sebayanya yang lain. Guru menciptakan suasana kelas yang nyaman serta menyenangkan bagi seluruh anak, hal ini juga menambahkan hal yang positif bagi anak tersebut. Guru juga turut memberikan penguatan terhadap kemunculan perilaku anak yang diharapkan. Terkait permasalahan pada pembelajaran yang ditemui, guru memberikan stimulasi secara berulang kepada anak. Contohnya pada pengenalan berhitung, guru menggunakan benda nyata yang menarik perhatian anak. Pada stimulasi bahasa anak, digunakan juga dengan metode bercerita dan tanya jawab kepada anak terkait cerita yang disampaikan oleh guru.

Peran guru di sekolah juga dengan memberikan pembelajaran melalui hal yang disukai oleh anak, setelah guru mengetahui apa yang disenangi oleh anak maka dapat memaksimalkan pembelajaran. Guru memberikan respon yang berbeda kepada anak dari orangtua Tenaga Kerja Indonesia (TKI), guru menyesuaikan gaya dan keinginan anak sesuai dengan minatnya masing-masing. Anak diberi kebebasan untuk melakukan kegiatan yang disenangi. Guru memfasilitasi anak agar berhasil menyelesaikan kegiatannya sendiri tanpa bantuan kakek nenek dengan cara memberikan arahan, mendekati, dan memberikan semangat. Guru memberikan respon yang mampu menstimulasi anak agar memiliki kemampuan sesuai usianya.

Hal lain yang dilakukan oleh guru adalah memberikan pendekatan yang lebih terhadap kakek-nenek dari keluarga anak tersebut, dengan bertujuan agar memberikan edukasi mengenai pengasuhan yang optimal bagi anak. Pendekatan kepada nenek biasa dilakukan ketika penjemputan anak, guru memberikan masukan dan laporan mengenai perkembangan anak. Selain itu juga disampaikan untuk memberikan stimulasi bagi anak sesuai dengan pembelajaran yang diberikan di sekolah. Usaha lain yang dilakukan adalah memberikan masukan kepada nenek terkait pengasuhan kepada anak ketika diadakan agenda pertemuan, kegiatan, ataupun rapat bersama wali anak. Disediakan waktu yang lebih banyak untuk berdiskusi pada nenek dari anak yang berasal dari keluarga Tenaga Kerja Indonesia (TKI). Usaha yang dilakukan oleh guru ini juga mampu untuk memberikan perubahan pada anak tersebut pada pencapaian perkembangan di sekolah. Pemberian contoh dan masukan kepada kakek-nenek juga dilakukan ketika di luar sekolah, karena guru serta murid memiliki lokasi rumah yang masih terjangkau dan berdekatan.

\section{Pengaruh Positif Peran Guru}

Peran dari guru ini mampu memberikan pengetahuan sedikit demi sedikit mengenai pola asuh kakek nenek ke arah otoritatif. Aspek perkembangan anak juga mulai mengarah sesuai usianya ketika sudah beranjak pada kelompok B, hal ini dikarenakan dengan adanya pendekatan serta peran guru ini. Meskipun pemberian arahan terkait pengasuhan belum bisa optimal dilakukan, namun kakek nenek merespons positif dan melakukan apa yang disarankan oleh guru. Permasalahan anak pada beberapa aspek perkembangan tentunya memerlukan penanganan dari guru agar anak tetap mampu optimal dalam mengikuti kegiatan di sekolah. Cara yang digunakan oleh guru dalam mengatasi hal tersebut adalah dengan menjalin kelekatan pada anak. Guru mendekati anak dan mengidentifikasi kekurangan serta kelebihan masing-masing. Melalui pendekatan yang dilakukan oleh guru, mulai terjalin rasa nyaman dan percaya dari anak kepada guru. Sehingga guru mulai bisa untuk mengendalikan anak serta mengetahui teknik pengajaran yang sesuai dengan anak. 
Dikarenakan pengasuhan yang tidak dilakukan secara langsung oleh ibunya, maka guru di taman kanak-kanak memiliki peran penting dalam mengoptimalkan seluruh aspek perkembangan anak tersebut. Peran guru di sekolah berpengaruh secara signifikan terhadap kepribadian anak (Setiadi \& Muhyani, 2017). Guru juga rutin memberikan penguatan terhadap perilaku anak yang sudah baik. Penguatan eksternal dapat berupa bentuk nyata dan memiliki wujud seperti hadiah, waktu bermain yang lebih banyak, dll, penguatan yang tidak berbentuk nyata dapat diberikan melalui senyuman, pujian, kalimat yang membanggakan anak, pelukan, perhatian lebih, atau perlakuan khusus. Dipaparkan oleh Baumrind bahwa apapun bentuk hadiah yang diberikan, anak harus melihatnya sebagai bentuk hadiah dan mendapatkannya secara konsisten setelah melakukan perilaku yang diinginkan (Papalia et al., 2015).

Guru terlibat langsung dalam memberikan pemahaman dan membangun kedekatan terhadap anak. Perlakuan yang diberikan oleh guru terhadap kakek nenek dan anak dapat memberikan perubahan ke arah yang positif terkait permasalahan anak. Para guru rata-rata memperoleh keuntungan sedang hingga besar dalam penggunaan perasaan ketika mengajar dan pemecahan masalah, dengan melakukan hal-hal seperti memberi label perasaan anakanak dan membantu mereka memecahkan masalah menggunakan kata-kata mereka (Conners-Burrow et al., 2016).

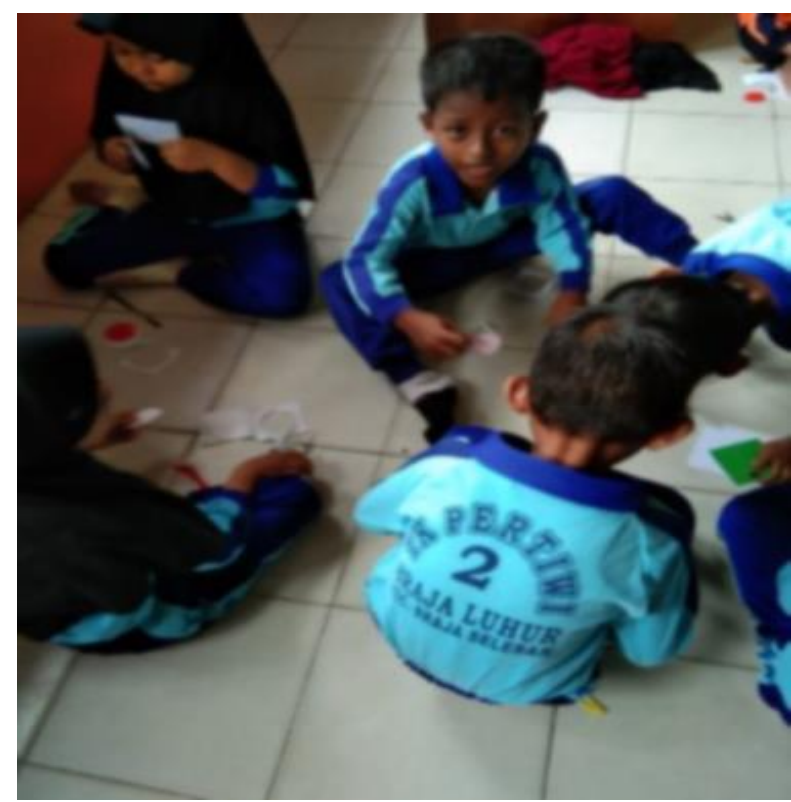

Gambar 2. Proses Pembelajaran

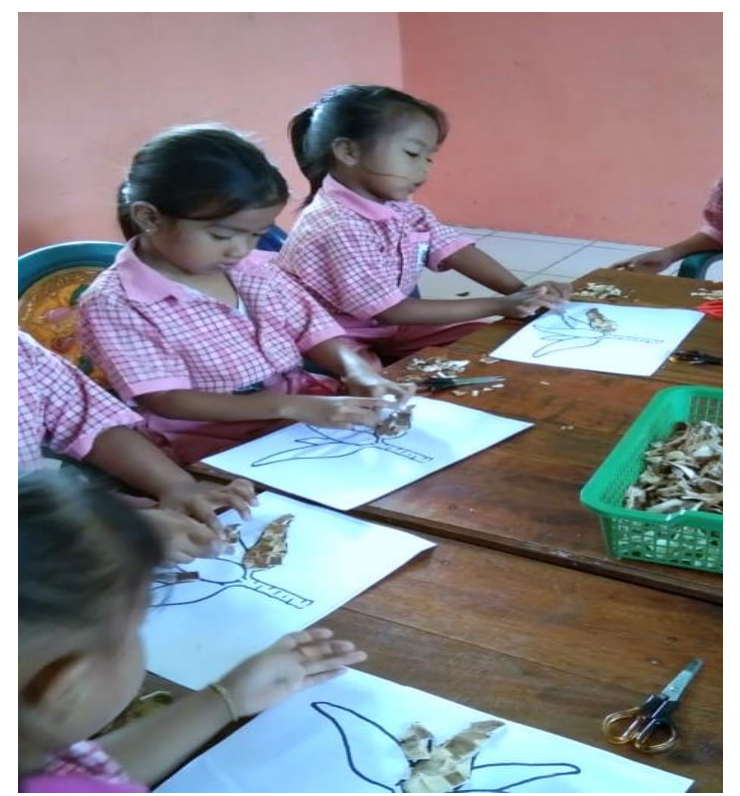

Gambar 3. Siswa dengan Orangtua TKI

Peran guru dengan memberikan masukan terkait pola asuh yang optimal terhadap anak usia dini juga memiliki pengaruh perubahan perilaku pada anak yang mengarah pada hal yang positif. Hal ini sesuai dengan penelitian oleh Setiawan (2017) bahwa guru mampu menuntun dengan benar bagi potensi siswa. Peran yang sangat penting dari guru PAUD adalah berinteraksi dengan anak-anak dengan cara yang sensitif dan responsif sehingga mempromosikan iklim kelas sosial dan emosional yang sehat. Iklim sosial dan emosional yang sehat mendukung kognitif, sosial, perkembangan emosional, fisik, dan perilaku (Hubel, dkk, 2020). Peran guru lebih berpengaruh terhadap kepribadian anak, dibandingkan dengan pola asuh orangtua (Setiadi \& Muhyani, 2017). Berbagai peran dan usaha guru ini akan semakin meningkatkan dan mengasah aspek perkembangan anak, terutama ketika anak sudah naik ke kelas B di taman kanak-kanak. 


\section{SIMPULAN}

Pola asuh yang mayoritas diterapkan dari keluarga Tenaga Kerja Indonesia di Desa Braja Luhur oleh kakek neneknya adalah permisif. Dampak aspek sosial emosional pada kemandirian, bahasa pada pengenalan huruf, dan kognitif pada pengenalan angka. Peran guru pada pengasuhan yang dilakukan nenek adalah memberikan waktu lebih lama dalam mendiskusikan hasil belajar anak di sekolah dan memberikan masukan terkait cara mengoptimalkan aspek perkembangan dengan cara pemberian stimulasi yang lebih ketika di rumah. Guru menyesuaikan gaya belajar sesuai minat anak serta menfasilitasi agar berhasil menyelesaikan kegiatannya sendiri. Peran guru ini memberikan perubahan positif pada pengasuhan serta anak dan dapat dicontoh oleh wilayah lain.

\section{UCAPAN TERIMA KASIH}

Selaku peneliti kami ucapkan terima kasih kepada semua pihak yang turut serta dalam mendukung penelitian ini hingga mampu terlaksana dengan baik. Kami ucapkan terima kasih juga kepada guru di Desa Braja Luhur, reviewer, dan tim dari jurnal obsesi.

\section{DAFTAR PUSTAKA}

Aziz, S. (2015). Pendidikan keluarga. Gava Media.

Badan Pelindungan Pekerja Migran Indonesia. (2020). Data Penempatan Dan Pelindungan Pmi Periode Januari 2020. Badan Pelindungan Pekerja Migran Indonesia, (9), 1689-1699.

Baumrind, D. (1991). The Influence of Parenting Style on Adolescent Competence and Substance Use. The Journal of Early Adolescence, 11(1), 56-95. https:/ / doi.org/10.1177/0272431691111004

Berns, R. M. (2007). Child family, school, community socialization, and support (7th ed.). Thomson Wadsworth

Brooks, J. (1986). The Process of Parenting (Book). Journal of Clinical Child Psychology, 15(4), 380-380. https://doi.org/10.1207/s15374424jccp1504_19

Cao, G., Li, K., Wang, R., \& Liu, T. (2017). Consumption Structure of Migrant Worker Families in China. China and World Economy, 25(4), 1-21. https://doi.org/10.1111/cwe.12203

Conners-Burrow, N. A., Patrick, T., Kyzer, A., \& Mckelvey, L. (2016). A preliminary evaluation of REACH : Training Early Childhood Teachers to support children ' s social and emotional development. Early Childhood Education Journal, 45(2), 187-199. https://doi.org/10.1007/s10643-016-0781-2

DPR. (2014). UU Nomor 39 Tahun 2004 Tentang Penempatan Dan Perlindungan Tenaga Kerja Indonesia Di Luar Negeri. Elsam. https:/ / referensi.elsam.or.id/2014/12/uu-nomor-39tahun-2004-tentang-penempatan-dan-perlindungan-tenaga-kerja-indonesia-di-luarnegeri/

Haryanti, \& Sumarno. (2014). Pemahaman kompetensi parenting terhadap perkembangan sosial anak. Jurnal Pendidikan Dan Pemberdayaan Masyarakat, 1(1), 32-49.

Hasan, M. (2009). Pendidikan anak usia dini. Diva Press.

Hasbi Indra. (2017). Pendidikan Keluarga Islam. PT Remaja Rosdakarya.

Herentina.T, Y. M. (2012). Peran Orang Tua DalamKegiatan Bermain Dalam perkembangan Kognitif Anak Usia Prasekolah (5-6 Tahun). Jurnal STIKES, Vol 5(No 2), 121-132.

Hidayati, A., Zuhdi, M. S., \& Islam, B. K. (2019). Pengaruh Keluarga (TKI) terhadap erpilaku disiplin belajar anak sd di kabupaten tulungangung. Jurnal Efektor, 6(2), 157-164. https://doi.org/10.29407/e.v6i2.13179

Nayana, F. N. (2013). Kefungsian Keluarga dan Subjective Well-Being Pada Remaja. Jurnal Ilmiah Psikologi Terapan, 1(2), 230-244. https://www.bertelsmannstiftung.de/fileadmin/files/BSt/Publikationen/GrauePublikationen/MT_Globalizat ion_Report_2018.pdf\%0Ahttp:// eprints.lse.ac.uk/43447/1/India_globalisation\%2C society and inequalities\%28lsero\%29.pdf\%0Ahttps://www.quora.com/What-is-the 
Nichols, M., Stein, A. D., \& Wold, J. L. (2014). Health status of children of migrant farm workers: Farm worker family health program, Moultrie, Georgia. American Journal of Public Health, 104(2), 365-370. https:/ / doi.org/10.2105/ AJPH.2013.301511

Nopitasari, R., \& Imelda, J. D. (2018). Perlindungan Dan Kesejahteraan Anak: Studi Deskriptif Pada Keluarga Tenaga Kerja Indonesia (Tki) Laki-Laki Di Lombok Timur. Jurnal Ilmu Kesejahteraan Sosial, 18(1), 18-33. https:// doi.org/10.7454/jurnalkessos.v18i1.35

Nurannisa, H., Hasanah, U., Keluarga, P. K., Teknik, F., Jakarta, U. N., Remaja, P. E., Gekbrong, K., \& Barat, C. (2017). Pengaruh granparenting terhadap perkembangan emosi remaja pada keluarga TKI di kecamatan gekbrong cianjur jawa barat. Jurnal Kesejahteraan Keluarga Dan Pendidikan, 4(2), 62-65. https:// doi.org/10.21009/JKKP.042.02

Papalia, D. E., Olds, S. W., \& Feldman, R. D. (2015). Menyelami perkembangan manusia. Salemba Humanika.

Safitri, Y. (2017). Faktor-Faktor yang Berhubungan dengan Perkembangan Bahasa Balita di UPTD Kesehatan Baserah Tahun 2016. 1(2), 148-155. https:/ / doi.org/10.31004/obsesi.v1i2.35

Santrock, J. W. (n.d.). Perkembangan anak. Jakarta: Erlangga, 1(2), 3.

Setiadi, H., \& Muhyani, M. (2017). Pengaruh Pola Asuh Orang Tua dan Peran Guru di Sekolah Terhadap Kesadaran Beragama dan Kepribadian Siswa. Uhamka Islamic Humanities and Social Sciences, 285-292.

Setiawan, A. (2017). Peran Guru Menurut Perspektif. Jakarta:UIN Syarif Hidayatullah.

Slamet, M., Kismiyati, E. K., \& Meria, O. (2018). The Reposition of Women's Role in Migrant Worker's Families in Karawang. E3S Web of Conferences, 73, 8-10. https:// doi.org/10.1051/e3sconf/20187311008

Sugiyono. (2017). Metode Penelitian Pendidikan: Pendekatan Kuantitatif, Kualitatif, R\&D. Cetakan Ke-25. Bandung: CV Alfabeta.

Suharto, M. P., \& Nurwati, N. (2018). Peran Extended Family Pada Anak Tkw Yang Terlantar Di Kabupaten Indramayu. Prosiding Penelitian Dan Pengabdian Kepada Masyarakat, 5(2), 165. https://doi.org/10.24198/jppm.v5i2.18368

Sutiana, M. A., Nandatia, R. P., A'yun, Q., Prayogi, A. R., \& Imron, A. (2018). Pola Pengasuhan Anak pada Keluarga TKW di Kecamatan Srengat Kabupaten Blitar. Paradigma, 06(01), 1-6.

Wijirahayu, A., Pranaji, D. K., \& Muflikhati, I. (2016). Kelekatan Ibu-Anak, Pertumbuhan Anak, dan Perkembangan Sosial Emosi Anak Usia Prasekolah. Jurnal Ilmu Keluarga Dan Konsumen, 9(3), 171-182. https://doi.org/10.24156/jikk.2016.9.3.171

Yuniastuti. (2014). Kehidupan Sosial Ekonomi TKI Dan TKW Serta Dampak Sosial Psikologis Pendidikan Anak. Jurnal Ilmiah Pendidikan Pancasila Dan Kewarganegaraan, 27(1), 69. 